\title{
Assessment of Contamination with Heavy Metals in Environment: Water, STERILE, Sludge and Soil around Kishnica Landfill, Kosovo
}

\author{
Bardha Korça, Skender Demaku* \\ Department of Chemistry, Faculty of Natural Sciences, University of Pristina, \\ Str. Mother Thereza, 5, 10000 Pristine, Republic of Kosovo
}

Received: 3 March 2020

Accepted: 14 May 2020

\begin{abstract}
This research paper represents the results of concentrations of heavy metals in; soil, water, waste after floatation and sludge at the landfill Kishnica mines in Kosovo. The waste material; after the flotation process and water after technological processes are directly discharged through the pipe into the surface of the soil, near the agricultural lands in this zone. This industrial discharge, with high concentration of heavy metals, has caused the land around this area to be highly contaminated by the waste of the junk materials being discharged from the $\mathrm{Pb}-\mathrm{Zn}$ industry in Kishnica. The sampling was performed in June 2018, while the measurements were done using atomic absorption spectroscopy (AAS).

In our results, we have found that the concentration of heavy metals in this analyzed zone around this area, has not exceeded the maximum amount allowed compared to EU-WHO standards, for contamination, and Dutch list for soils and Interventions.
\end{abstract}

Keywords: heavy metals, soil, water, sludge, Kishnica Complex

\section{Introduction}

Studies showed that anthropogenic activities are the main source of metal contamination in the environment. Environment can get polluted or contaminated by different organic, inorganic and heavy metals substances. Heavy metal toxicity disrupts natural ecosystems and affects the food chain and different living organisms leading to different health problems. Once metals are introduced into the environment, they undergo several biological and chemical processes that

*e-mail: skender.demaku@hotmail.com lead to their distribution in environmental compartments such soils, sediments, water etc, [1-2].

The Kishnica mines are part of the industrial complex of Trepça, located in the northeastern part of Kosovo, in the Graçanica municipality area, just a couple of kilometers away from capital city, Prishtina. These mines, with their production capacities, discharge large amounts of waste into the environment because ore is only a small fraction of the total volume of processed material, around $30 \%$ for $\mathrm{Pb}$ residuals, and 50 $\%$ for residual waste $\mathrm{Zn}$, which is the remnant of the mineralization process at the Kishnica flotation. The Kishnica mineral mines are considered as one of the most important $\mathrm{Pb}-\mathrm{Zn}$ deposits in the mining area in Kosovo. 
The need to do this study is that heavy metals are not biodegradable in the environment, and are involved in the biogeochemical cycles through which they are concentrated in the sediment, and in the living organisms. Therefore, this research is very important since these elements can easily end up in the food chain. In order to evaluate the environmental pollution in water, soil and sludge we measured heavy metals $(\mathrm{Pb}, \mathrm{Zn}, \mathrm{Cu}, \mathrm{Cd}, \mathrm{Ni}$ and $\mathrm{Fe}$ ) using AAS technique.

\section{Materials and Methods}

Study Area

The scheme below shows sampling points for water, soil, waste after floatation and sludge near Kishnica mines. The samples were taken around Graçanka River, as shown in the Fig. 1.

\section{Sample Collection of Waste after Floatation}

For the sampling we chose different spots that represent water, soil, wastes and sludge. The waste material after floatation was taken in amount of around 1-2 $\mathrm{kg}$ from four different locations. The first sample was collected in the northern part of the landfill, the second in front of the flotation plant in Kishnica, the third sample in the southern part of the mine and the last one in the middle of the landfill. From the collected samples, we prepared the representative sample for chemical analysis. Initially we mixed and homogenized the samples, and then divided them into four equal parts, about $900 \mathrm{~g}$, then the we mixed and crushed it and then we used the sample as a mat, for further chemical analysis.

\section{Sample Collection of Soil}

In order to have representative data, we focused on four different locations to take the soil samples, in an area with lower impact of the material waste at the landfill, close to the playground field of the Kishnica Club, near the waste of the landfill material and the garbage of Graçanica town; and the fourth one in an agricultural land-2.5 km from the town of Graçanica. All the samples were dried in $105^{\circ} \mathrm{C}$, until they were brought to constant weight.

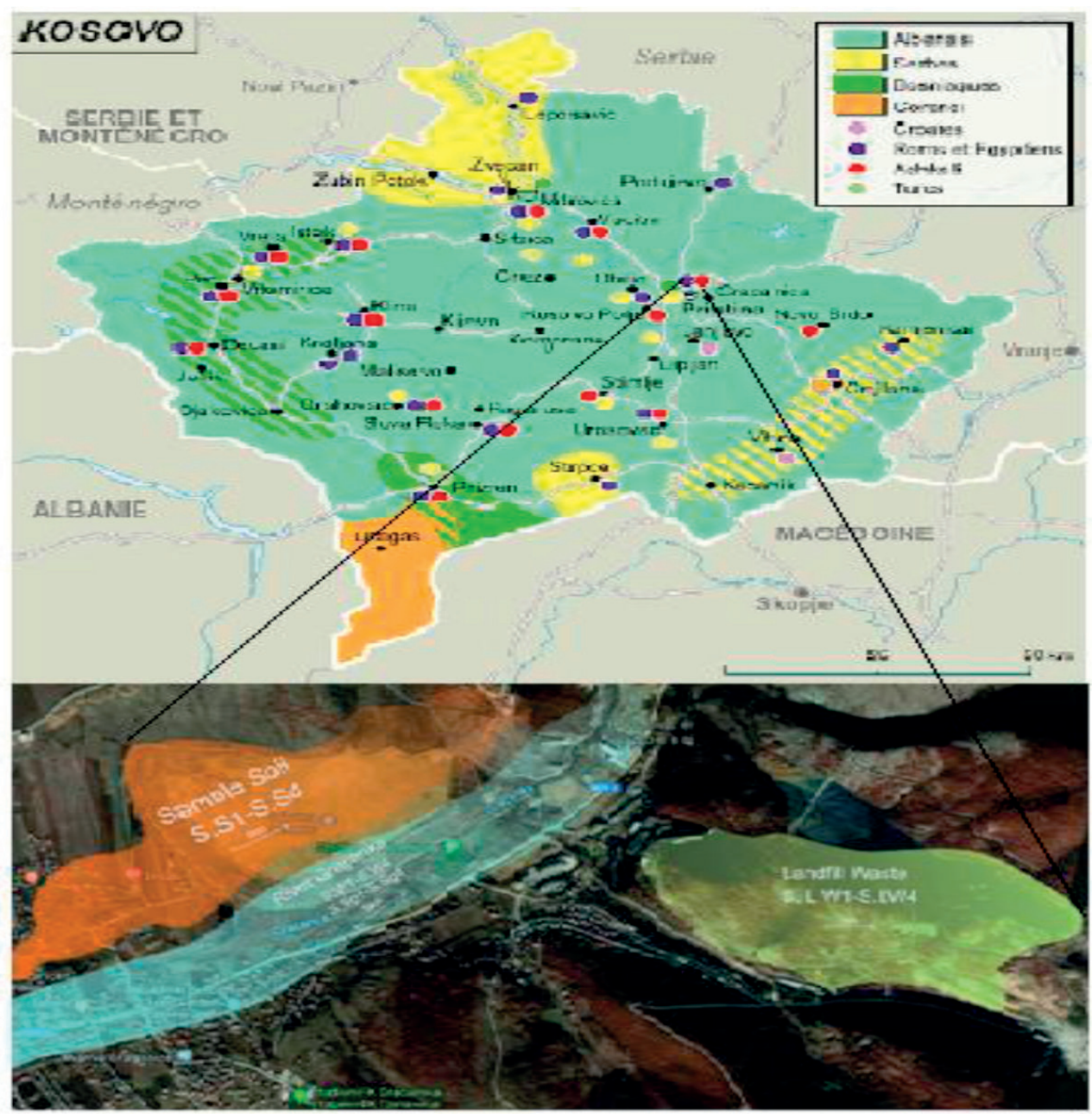

Fig. 1. Study area near Kishnica, around Graçanka River. 


\section{Water Collection and Digestion}

Water samples were taken around Graçanica River. The samples were taken near Badovc Lake; waste water discharge pipe; directly to the pipe and the last one in Graçanica River in town of Graçanica. First, water samples were filtered, before placing a $50 \mathrm{ml}$ aliquot into Teflon vessels. Samples were then treated with $1 \mathrm{~mL}$ of $\mathrm{HCl}$ and $5 \mathrm{~mL}$ of $\mathrm{HNO}_{3}$ and digested in a BERGHOF-Speed Wave microwave.

\section{Sludge Chemical Analysis}

In order to determine the heavy metals contents in sludge, for the digestion of chemical elements in the sludge we used acid mixtures; perchloric acid and nitric acid (ratio 1: 4). For chemical analysis, we got around$0.25 \mathrm{~g}$ of dried matter of sludge initially at $105^{\circ} \mathrm{C}$ then to we cooled them to room temperature. We dissolved samples in the mixture of $10 \mathrm{ml}$ of perchloric acid and nitric acid digested the sample into the homogenization. After the process was done, we filtered, leveled the sample to $100 \mathrm{ml}$ with distillated water. We measured the heavy metals using atomic absorption spectroscopy (AAS).

\section{Results and Discussions}

The aim of this study is to evaluate the presence of $\mathrm{Pb}, \mathrm{Zn}, \mathrm{Cu}, \mathrm{Cd}, \mathrm{Ni}$ and $\mathrm{Fe}$ in water, soil, sludge and waste material after floatation sampled in the vicinity of industrial complex "Kishnica" as a possible pollution site. The results are presented in $\mathrm{mg} / \mathrm{kg}$ of a dry mass for elements and divided into four groups:

\section{Determination of Pollutants in Wastes after Flotation Processes}

Different studies have shown that environmental pollution can come from mining [4-6]. Various research also concluded that open-pit mining produces around ten times as much waste as underground mines because a greater amount of topsoil, overburden and barren or waste rock has to be removed. Gold mining in South Africa over the centuries has resulted in the accumulation of thousands of voluminous tailings dumps which are scattered all over the country with lots of potentially negative impact on the environments [7].

Fig. 2 shows the similarity distribution of $\mathrm{Pb}, \mathrm{Zn}$, $\mathrm{Cu}, \mathrm{Cd}, \mathrm{Ni}$ and $\mathrm{Fe}$ in waste measured samples. The results are presented in $\mathrm{mg} / \mathrm{kg}$.

The dendogram presented above, represent the similarity percentage of lead, zinc, cadmium, iron, copper and nickel in waste samples. From the results obtained, the similarity between $\mathrm{Cd}$ in $\mathrm{Fe}$ is the highest, almost $99.99 \%$. The similarity between zinc and the group of cadmium and iron is also very high, with almost $95 \%$. It is shown that the high percentage is

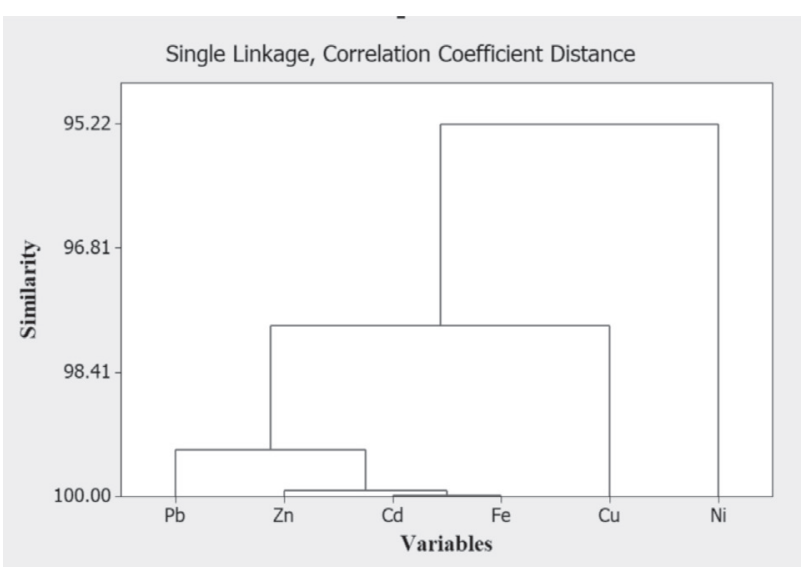

Fig. 2. Distribution dendogram of $\mathrm{Pb}, \mathrm{Zn}, \mathrm{Cd}, \mathrm{Fe}, \mathrm{Cu}$ and $\mathrm{Ni}$ in analyzed samples of waste.

between the lead and zinc and that we can conclude that the source of contamination with this metal comes from Kishnica mines.

The Fig. 3 represents the histogram of normal distribution of these elements $(\mathrm{Pb}, \mathrm{Zn}, \mathrm{Cd}, \mathrm{Fe}, \mathrm{Cu}$ and $\mathrm{Ni}$ ) in $\mathrm{mg} / \mathrm{kg}$.

\section{Determination of Water Pollution from Kishnica Mines}

Heavy metal pollution is caused when different toxic metals contained in excavated rock or exposed in an underground mine come in contact with water. Metals can end up in water during the process of water washes over the rock surface. Metals can become mobile in neutral $\mathrm{pH}$ conditions, leaching are particularly accelerated in the low $\mathrm{pH}$ conditions. Contaminations of surface and ground water have particularly been experienced in mining communities [8]. Mining has played a significant role in the socioeconomic life of the world for the past hundreds of years [9].

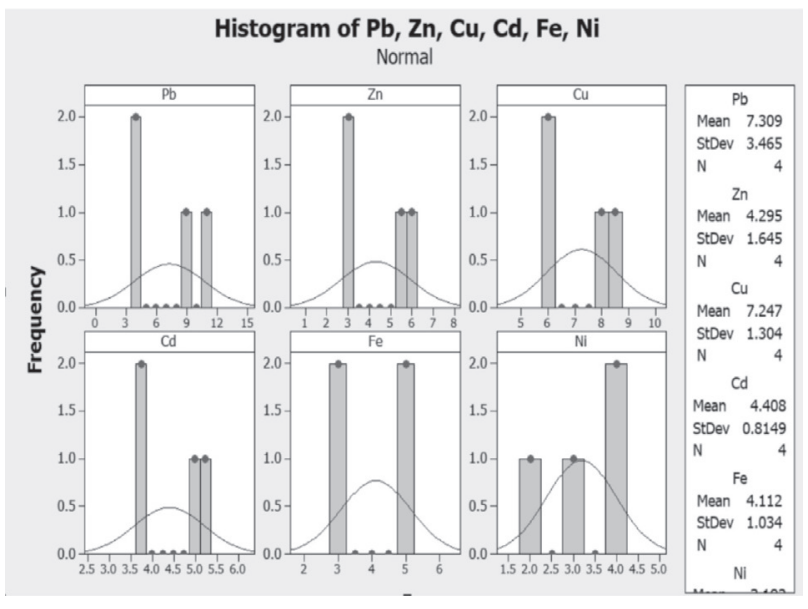

Fig. 3. Distribution of elements in waste analyzed samples $(\mathrm{mg} / \mathrm{kg})$. 


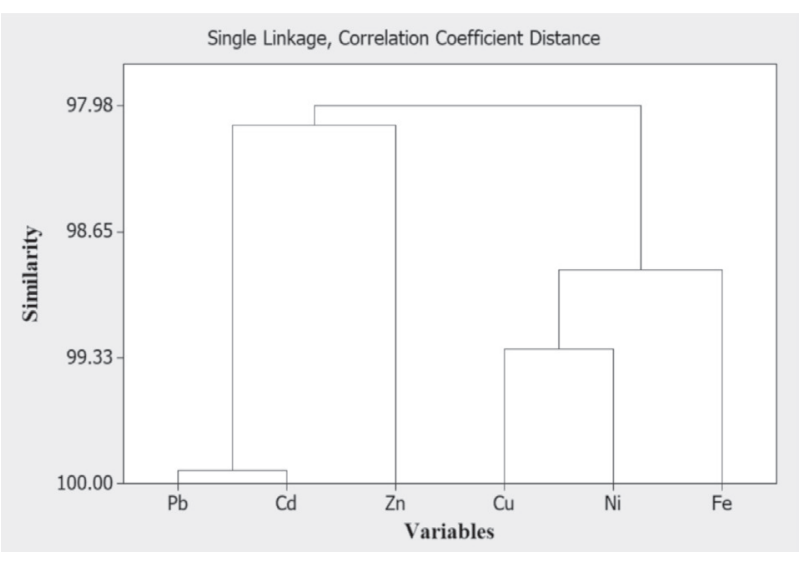

Fig. 4. Distribution dendogram of $\mathrm{Pb}, \mathrm{Zn}, \mathrm{Cd}, \mathrm{Fe}, \mathrm{Cu}$ and $\mathrm{Ni}$ in analyzed samples of water.

Fig. 4 represents the similarity distribution of $\mathrm{Pb}$, $\mathrm{Zn}, \mathrm{Cu}, \mathrm{Cd}, \mathrm{Ni}$ and $\mathrm{Fe}$ in water pollution measured samples. The results are presented in $\mathrm{mg} / \mathrm{kg}$. Fig. 5 shows the normal distribution of these elements in water samples measured, represented in $\mathrm{mg} / \mathrm{kg}$

The dendogram presented above, represent the similarity percentage of lead, zinc, cadmium, iron, copper and nickel in water samples. From the results obtained, the similarity between $\mathrm{Cd}$ and $\mathrm{Pb}$ is the highest, almost $100 \%$. The similarity between zinc and the group of cadmium and $\mathrm{Pb}$ in this case is around $96 \%$. Also, it is shown that the high percentage is between the three other elements; copper and nickel around $98 \%$ while iron with this group has the similarity of $97 \%$. From the results obtained we can conclude that the source of contamination with these elements comes from Kishnica mines.

Regarding the concentration of heavy metals in the river Graçanica, we can present the order of growth of these chemical elements, as follows; $\mathrm{Pb}>\mathrm{Cu}>\mathrm{Fe}>\mathrm{Cd}>$ $\mathrm{Zn}$ and $\mathrm{Ni}$. If we compare the results to EU standards,

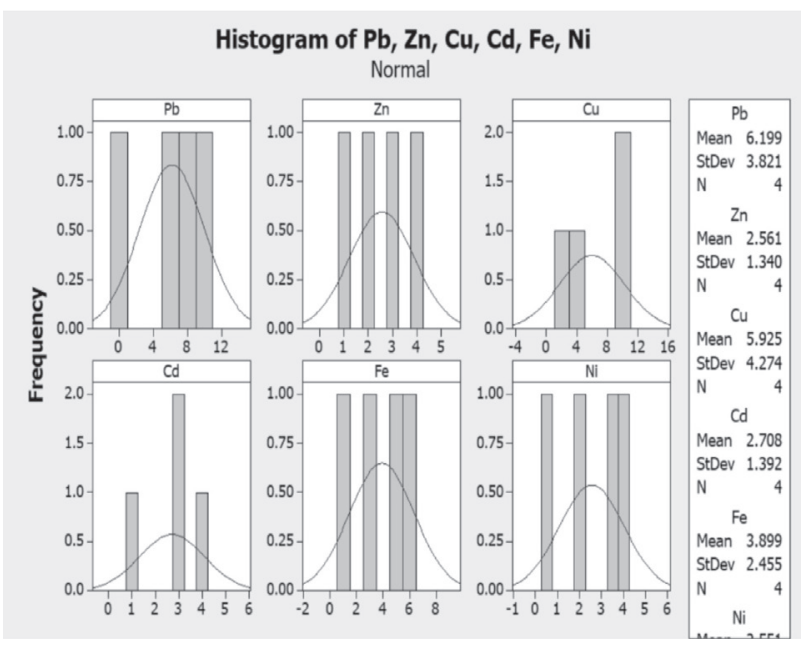

Fig. 5. Distribution of elements in waste analyzed samples $(\mathrm{mg} / \mathrm{kg})$.

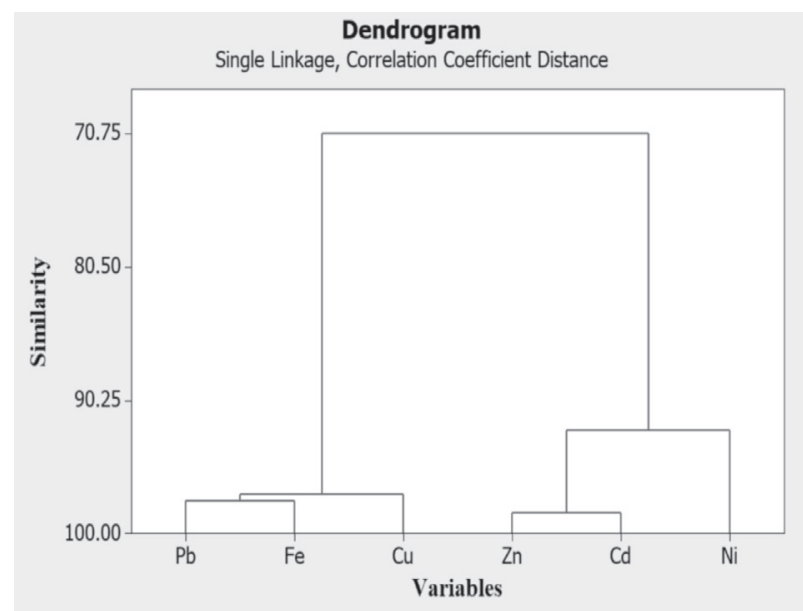

Fig. 6. Distribution dendogram of $\mathrm{Pb}, \mathrm{Zn}, \mathrm{Cd}, \mathrm{Fe}, \mathrm{Cu}$ and $\mathrm{Ni}$ in analyzed soil samples.

respectively directive 2008/105/EC [15], almost all chemical elements found in the river Graçanica exceed the limited under this Directive.

\section{Determination of Agricultural Soil Pollution from Kishnica Mines}

Soil heavy metal pollution has become a severe problem in many parts of the world [10]. Different studies [11-12], stated that rapid social and economic development over the past several decades caused serious soil pollution with heavy metals in China. It is also stated that the pollution with these elements may occur naturally in soil and additional contributions come from anthropogenic activities such as agriculture, urbanization, industrialization, and mining.

Fig. 6 represents the similarity distribution of $\mathrm{Pb}, \mathrm{Zn}$, $\mathrm{Cu}, \mathrm{Cd}, \mathrm{Ni}$, and $\mathrm{Fe}$ in soil pollution measured samples. The results are presented in $\mathrm{mg} / \mathrm{kg}$. Fig. 7 shows the normal distribution of these elements in $\mathrm{mg} / \mathrm{kg}$.

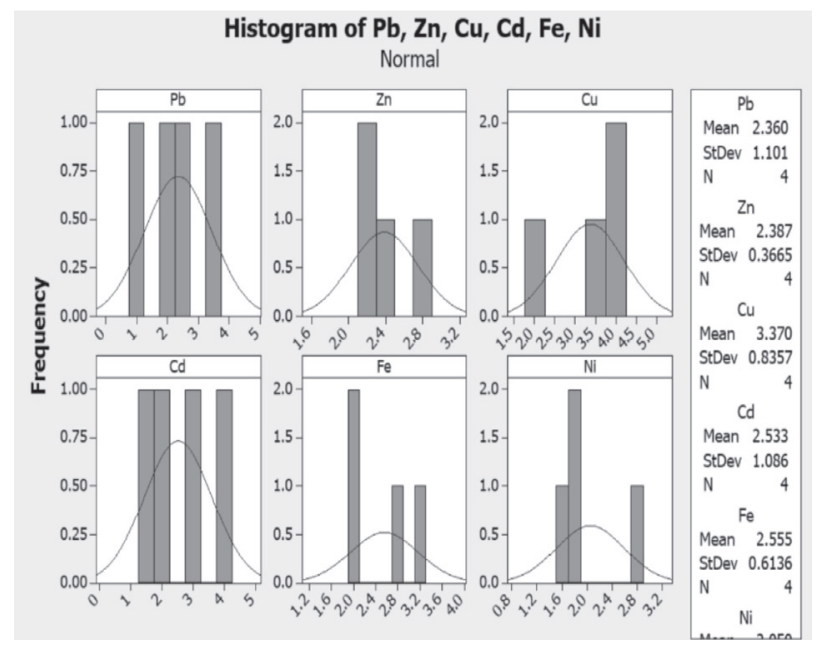

Fig. 7. Distribution of elements in analyzed soil samples $(\mathrm{mg} / \mathrm{kg})$. 
In this element combination there is a lower scale of probability similarity than in the other groups; waste and water determination.

The highest concentration of the elements in this case is shown by $\mathrm{Cu}>\mathrm{Pb}>\mathrm{Fe}>\mathrm{Cd}>\mathrm{Zn}$ and $\mathrm{Ni}$. If we compare them as a similarity of their distribution, we can say that they are divided into two bigger categories: $\mathrm{Pb}$ and $\mathrm{Fe}$ with $97 \%$ of similarity and also the group of $\mathrm{Zn}$ and $\mathrm{Cd}$, with around $92 \%$.

Fig. 7 presents the histogram of heavy metals in agricultural soils around Kishnica in Gracanica, Kosovo.

\section{Determination of Sludge Pollution from Kishnica Mines}

The production of sewage sludge increases every year that comes from population growth, industry growth etc. It is mentioned that the production of sludge in European Union (EU) is going to reach around 13,000,000 tons of dry matter. Sludge can contain different pollutions, inorganic and organic ones, including the toxic heavy metals, i.e., cadmium (Cd), chromium $(\mathrm{Cr})$, copper $(\mathrm{Cu})$, mercury $(\mathrm{Hg})$, nickel $(\mathrm{Ni})$, lead $(\mathrm{Pb})$ and zinc $(\mathrm{Zn})$ etc. Our study represents the pollution of sludge with heavy metals from Kishnica mines in Kosovo. Fig. 8 represents the similarity distribution of $\mathrm{Pb}, \mathrm{Zn}, \mathrm{Cu}, \mathrm{Cd}, \mathrm{Ni}$ and $\mathrm{Fe}$ in sludge pollution measured samples. The results are presented in $\mathrm{mg} / \mathrm{kg}$. Fig. 9 shows the normal distribution of these elements in $\mathrm{mg} / \mathrm{kg}$.

In the case of distribution diagram of these elements in sludge, we have the results divided into two major groups: $\mathrm{Pb}, \mathrm{Zn}$ and $\mathrm{Cd}$ in one and in the other hand between $\mathrm{Cu}, \mathrm{Fe}$ and $\mathrm{Ni}$. The first group of elements showed a similarity of about $99 \%$ and the second one where copper, iron and nickel are, showed the similarity of $98 \%$.

To obtain more comparable results, we also extracted other tabular data that include various statistical variables. The following table (Table 1) is a summary of all results in the form of statistical analyzes

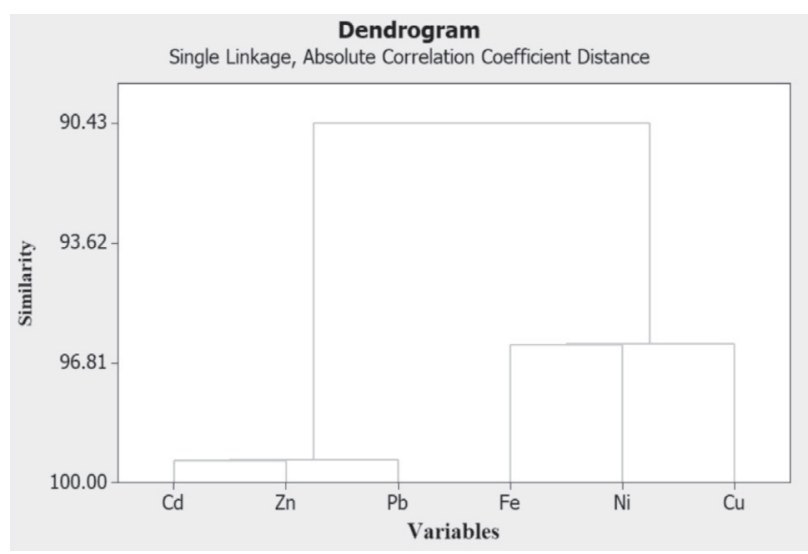

Fig. 8. Distribution of elements in analyzed soil samples $(\mathrm{mg} / \mathrm{kg})$.

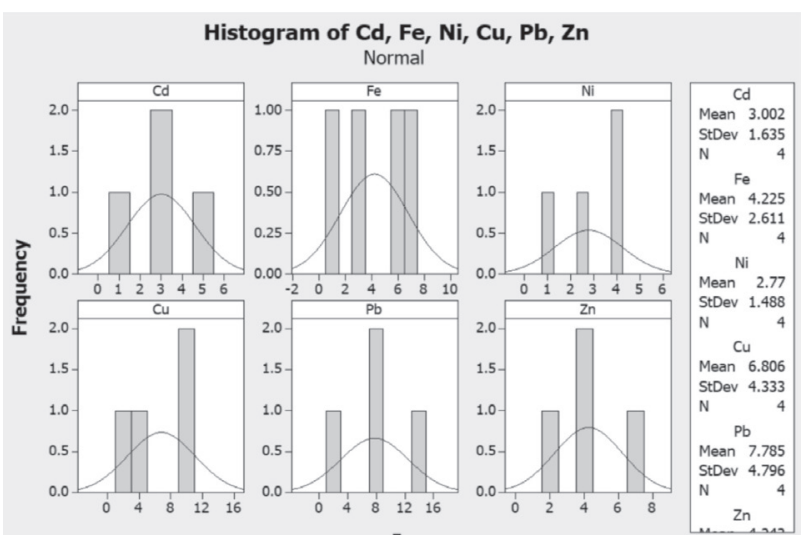

Fig. 9. Distribution of elements in analyzed soil samples $(\mathrm{mg} / \mathrm{kg})$.

of measurements made on waste after floatation, water, soil and sludge samples. The results are presented as mean, standard deviation, minimum, median and maximum. Results are presented in $\mathrm{mg} / \mathrm{kg}$.

Lead is a heavy metal present as a naturally found element on Earth, but also but anthropogenic activities, including mines ones can contribute to increase the concentrations of lead. It is a toxic metal that affects several organs in the body: kidneys, liver, central nervous system etc [13]. If we separate each element, we see that the concentration of lead decreased in order of the measured samples of: sludge, waste after floatation, water and soil samples, while the lowest concentration of this element was found in water $(0.9 \mathrm{mg} / \mathrm{kg})$, soils, sludge and in waste after floatation with the lowest concentration of $4.4 \mathrm{mg} / \mathrm{kg}$.

World Health Organization classifies zinc as an element that is essential for living organisms, and its deficiency can cause different diseases in human body. Concentration of $\mathrm{Zn}$ in the water ranges from 0.978 as the lowest concentration to $4.136 \mathrm{mg} / \mathrm{kg}$. The highest concentration was observed in the sludge samples starting from $1.88-6.77 \mathrm{mg} / \mathrm{kg}$ as the highest result.

Copper is considered an essential metal, along with different other elements including; iron, magnesium, selenium, calcium etc. This element plays an important role for different biochemical and physiological functions, and the deficiency of these elements can cause different diseases or syndromes. In our samples, copper concentrations ranged from $1.05 \mathrm{mg} / \mathrm{kg}$ as the lowest concentration found in water to $10.9 \mathrm{mg} / \mathrm{kg}$ found in sludge.

Decades ago, a disease "itai-itai" in Japan was spread, which was caused by the cadmium pollution [14]. Today it is known fact that cadmium is a toxic heavy metal which can be accumulated in the human body and in the environment long-term.

According to the results presented concentration of $\mathrm{Cd}$ in our soil samples ranged from 1.513 to $3.831 \mathrm{mg} / \mathrm{kg}$, while the target value of this element in soils according to the Dutch standard list is $0.8 \mathrm{mg} / \mathrm{kg}$ 
Table 1. Descriptive statistics of heavy metals in waste, water, soils and sludge $(\mathrm{mg} / \mathrm{kg})$.

\begin{tabular}{|c|c|c|c|c|c|}
\hline \multicolumn{6}{|c|}{ Elements in waste after floatation, presented in $\mathrm{mg} / \mathrm{kg}$. } \\
\hline Variable & Mean & StDev & Minimum & Median & Maximum \\
\hline $\mathrm{Pb}$ & 7.31 & 3.46 & 4.40 & 6.69 & 11.45 \\
\hline $\mathrm{Zn}$ & 4.295 & 1.645 & 2.875 & 4.148 & 6.009 \\
\hline $\mathrm{Cu}$ & 7.246 & 1.304 & 6.137 & 7.080 & 8.689 \\
\hline $\mathrm{Cd}$ & 4.408 & 0.815 & 3.689 & 4.366 & 5.211 \\
\hline $\mathrm{Fe}$ & 4.112 & 1.034 & 3.211 & 4.064 & 5.110 \\
\hline $\mathrm{Ni}$ & 3.192 & 0.811 & 2.135 & 3.367 & 3.900 \\
\hline \multicolumn{6}{|c|}{ Elements in water presented in $\mathrm{mg} / \mathrm{kg}$} \\
\hline $\mathrm{Pb}$ & 6.20 & 3.82 & 0.90 & 6.95 & 10.00 \\
\hline $\mathrm{Zn}$ & 2.561 & 1.340 & 0.978 & 2.564 & 4.136 \\
\hline $\mathrm{Cu}$ & 5.93 & 4.27 & 1.05 & 6.34 & 9.97 \\
\hline $\mathrm{Cd}$ & 2.708 & 1.392 & 0.822 & 2.918 & 4.174 \\
\hline $\mathrm{Fe}$ & 3.90 & 2.46 & 0.90 & 4.15 & 6.39 \\
\hline $\mathrm{Ni}$ & 2.551 & 1.482 & 0.650 & 2.888 & 3.779 \\
\hline \multicolumn{6}{|c|}{ Elements presented in soils $(\mathrm{mg} / \mathrm{kg})$} \\
\hline $\mathrm{Pb}$ & 2.360 & 1.101 & 1.073 & 2.338 & 3.689 \\
\hline $\mathrm{Zn}$ & 2.387 & 0.367 & 2.111 & 2.274 & 2.889 \\
\hline $\mathrm{Cu}$ & 3.370 & 0.836 & 2.193 & 3.595 & 4.097 \\
\hline $\mathrm{Cd}$ & 2.534 & 1.086 & 1.513 & 2.395 & 3.831 \\
\hline $\mathrm{Fe}$ & 2.555 & 0.614 & 2.009 & 2.457 & 3.300 \\
\hline $\mathrm{Ni}$ & 2.050 & 0.541 & 1.685 & 1.832 & 2.852 \\
\hline \multicolumn{6}{|c|}{ Elements presented in sludge (mg/kg) } \\
\hline $\mathrm{Pb}$ & 7.78 & 4.80 & 1.38 & 8.37 & 13.01 \\
\hline $\mathrm{Zn}$ & 4.24 & 2.00 & 1.88 & 4.16 & 6.77 \\
\hline $\mathrm{Cu}$ & 6.81 & 4.33 & 1.99 & 7.17 & 10.90 \\
\hline $\mathrm{Cd}$ & 3.002 & 1.635 & 0.936 & 3.069 & 4.934 \\
\hline $\mathrm{Fe}$ & 4.22 & 2.61 & 1.10 & 4.46 & 6.88 \\
\hline $\mathrm{Ni}$ & 2.770 & 1.488 & 0.774 & 3.160 & 3.987 \\
\hline
\end{tabular}

[16-17]. So, the results are a little higher than the target value, but none of the sample exceeded the amount of $12 \mathrm{mg} / \mathrm{kg}$, value that is the Dutch standard for intervention. The lowest concentration was observed in water with the concentration of $0.822 \mathrm{mg} / \mathrm{kg}$, while the highest concentration was recorded in waste products after floatation with concentration $5.211 \mathrm{mg} / \mathrm{kg}$.

Nickel is an essential metal for living organisms and toxicity symptoms can occur when the redundancy or deficiency of this element might happen. For Ni, we observed higher concentrations in sludge $>$ waste $>$ water $>$ soils, [16] in all of the samples not exceeding the concentration of more than $4 \mathrm{mg} / \mathrm{kg}$. The lowest concentration of this element was presented in water $<$ sludge $<$ soils $<$ waste products, not exceeding more than $2.135 \mathrm{mg} / \mathrm{kg}$.

If we compare the whole results, we can conclude that we are dealing with low scale of pollution with heavy metals in this zone. This also can be justified due to the fact that activity of this mine has been shut down for a long time now, fortunately in this case making the pollution less in this zone.

\section{Conclusion}

The environmental problems in Kosovo in general have been huge, especially in the last two decades, 
categorizing the environmental issues as a "luxury" and with less priority. Ecological and environmental issues coming from mines: Trepça, Kishnica, Ferronickel and so on, have aggravated over the last few decades, threatening environmental devastation not only in those regions, but also in a bigger scale. The specific risk associated with these heavy metals $(\mathrm{Pb}, \mathrm{Zn}, \mathrm{Ni}, \mathrm{Cd}, \mathrm{Cu}$, and $\mathrm{Fe}$ ) in the environment it is not only pollution, but also their ability and bioaccumulation through the food chain, and their persistence in nature.

In this study, several metals $(\mathrm{Pb}, \mathrm{Zn}, \mathrm{Ni}, \mathrm{Cd}, \mathrm{Cu}$ and $\mathrm{Fe}$ ) were analyzed in four types of samples: water, soil, sludge and waste after the floatation in four different sampling positions. Results demonstrate that the presence of these metals in environmental samples has a common source: the concentrate type used in mining activities at Kishnica.

Since this ore is not active at the moment, we are dealing with low pollution in this zone. But, to keep it constant this zone and under control, to know the extent of contamination more accurately, it is preferable to continue with constant monitoring so that the zone does not exceed the maximum amount allowed with pollution in this zone.

\section{Acknowledgements}

The authors participated in the payment for the publication.

\section{Conflict of Interest}

The authors declare no conflict of interest.

\section{References}

1. VHAHANGWELE M., and KHATHUTSHELO L. Environmental Contamination by Heavy Metals. Muedi (June 27 $7^{\text {th }}$ 2018). Intech Open, DOI: 10.5772/ intechopen.76082. 2018.

2. EWA S., KAJETAN D. Long-term changes in surface and groundwater quality in the area of a municipal landfill (Barycz, Poland). 44 (1) DOI: 10.5277/epe180108. Environment Protection Engineering. 2018.

3. WENHAO W., RUI MA., ZIYONG SUN., AIGUO ZHOU., JIANWEI BU., XIANG LONG and YUNDE LIU. Effects of Mining Activities on the Release of Heavy Metals (HMs) in a Typical Mountain Headwater Region, the Qinghai-Tibet Plateau in China, International Journal of Environmental Research and Public Health, 15, 1, 2018.

4. UGYA A., AJIBADE F.O., AJIBADE T.F. Water Pollution Resulting From Mining Activity: An Overview,
Proceedings of the 2018 Annual Conference of the School of Engineering \& Engineering Technology, FUTA, 17-19 July. 2018.

5. SHUNHONG H., CUIYU Y., QIAN Li., YI Y., CHONGJIAN T., KUN O., BING W. Distribution and Risk Assessment of Heavy Metals in Soils from a Typical $\mathrm{Pb}-\mathrm{Zn}$ Mining Area, Pol. J. Environ. Stud. 26, (3), 1105, 2017.

6. ZHANGXIONG H., DEJUN W., HAIXIA T., WENXIANG H., ZIQUAN W., QIANG L. Pollution Assessment of Heavy Metals in Soils and Plants around Molybdenum Mine in Central China, Pol. J. Environ. Stud. 28 (1), 123, 2019.

7. MUIBAT O.F., VERONICA M.N.J., OLUBUKOLA O.B. Heavy Metal Pollution from Gold Mines: Environmental Effects and Bacterial Strategies for Resistance, Int. J. Environ. Res. Public Health. 13, 1047; doi:10.3390/ ijerph13111047. 2016.

8. ISAAC K.A. Monitoring Water Quality in River Bodies of Mining Communities in Ghana, Asian Journal of Humanities and Social Sciences (AJHSS) 3 (1), February, 20, 2015.

9. AKABZAA T.M., BANOENG-Y.B.K., SEYIRE J.S. Impact of Mining Activities on Water in the Vicinity of the Obuasi Mine. 2005.

10. SOLGI E., ESMAILI-S. A., RIYAHI B. A., HADIPOUR M. Soil contamination of metals in the three industrial estates, Arak, Iran. Bull Environ Contam Toxicol; 88, 634, 2012.

11. SODANGO T.H. Review of the Spatial Distribution, Source and Extent of Heavy Metal Pollution of Soil in China: Impacts and Mitigation Approaches." Journal of health \& pollution 8 (17) 53, 12 Mar, doi:10.5696/21569614-8.17.53. 2018.

12. QIANQI Y., ZHIYUAN LI., XIAONING LU, QIANNAN D., LEI H., JUN BI. A review of soil heavy metal pollution from industrial and agricultural regions in China: Pollution and risk assessment, Science of The Total Environment Volume 642, 15 November, 690, 2018.

13. AGENCY FOR TOXIC SUBSTANCES AND DISEASE REGISTRY (ATSDR. Public Health Service. Atlanta: U.S. Department of Health and Human Services; 1999. Toxicological Profile for Lead, 1999.

14. JING-XIU H., QI SH., YU DU. Review: effect of environmental cadmium pollution on human health" Health, 1 (3), 159, 2009.

15. Directive 2008/105/EC of the European Parliament and of the Council of 16 December 2008 on environmental quality standards in the field of water policy, amending and subsequently repealing Council Directives 82/176/ EEC, 83/513/EEC, 84/156/EEC, 84/491/EEC, 86/280/EEC. 2008.

16. WANG Y.C., AO L., LEI B., ZHANG S. Assessment of heavy metal contamination from sediment and soil in the riparian zone China's Three Gorges Reservoir. Polish Journal of Environmental Studies 24 (5), 2253, 2015.

17. Dutch Target and Intervention Values, 2000 (the New Dutch List). www.esdat.net/ Environmental Standards/ Dutch/annexs-I2000, Dutch Environmental Standards. Pdf. 2000. 
